\title{
Kolozsvár intézményeiröl
}

\section{SzEgedi Éva* \\ KÖNYVKÖTŐK ÉS KÖNYVKERESKEDŐK A 19. SZÁZADI KOLOZSVÁRON}

\author{
Kulcsszavak: könyvkötők, könyvkereskedők, Tilsch János, Barra Gábor, Stein János, \\ Kolozsvár
}

A tudomány és kultúra fejlődése érdekében II. József cenzúraszervezete a korábbinál kevesebb szigorral ítélkezett, és könyvnyomdák, kereskedések alapítását szorgalmazta. A könyvkereskedők tevékenységének feltételeit az 1772-es szabályzat foglalta össze (Ordo pro bibliopolis in Hungaria stabiliter manentibus), ${ }^{1}$ mely a könyvkereskedői szakma művelését hatévi tanulóidőhöz, négyévi gyakorlathoz, megfelelő nyelvtudáshoz és bizonyos pénzalaphoz kötötte. A könyvnyomtatóknak és könyvkötőknek csak azt volt szabad forgalmazniuk, amire jogosítványt kaptak, az idegen könyvkereskedők is csak vásárok idején árulhattak. ${ }^{2}$

Kókay György az első könyvkereskedést 1774-re datálja, melyet Kolozsváron Josef Franz Kollmann bécsi nyomdász alapított, illetve 1778-ra a hochmeisteri szabadalom megszerzését. ${ }^{3}$ Ballagi Aladár szerint Erdélyben az első könyvkereskedői szabadalmat Hochmeister Márton szebeni nyomdász kapta 1777-ben. Két évvel később itt nyitották meg könyvesboltjukat Barth, Gromen és Gänselmeier. ${ }^{4}$ Ferenczi Zoltán ${ }^{5}$ 1775-re teszi a Kollmann-féle kereskedés megnyitását, aki az egyetemi nyomda bérlője is volt 1774-1783 között és kiadói jelvénnyel is rendelkezett. ${ }^{6} \mathrm{Az}$ olvasnivalót, főként tankönyveket, énekeskönyveket és vallásos kiadványokat - leggyakrabban debreceni és pesti vásárokból szállították a kereskedők Erdélybe, melyek kifizetéséig a következő vásárig kellett várniuk a kiadóknak. A 18. század végén

* Szegedi Éva (1983), drd., fókönyvtáros, Kolozsvári Központi Egyetemi Könyvtár. E-mail: eva.szegedi@bcucluj.ro

1 KóкаY György: A könyvkereskedelem Magyarországon. Balassi Kiadó, Bp., 1997. 52.

2 Uo. 53.

3 Uo. 56.

4 Ballagi Aladár: A magyar nyomdászat történelmi fejlödése. 1472-1877. Franklin társulat, Bp., 1878. 135.

5 Ferenczi Zoltán: A kolozsvári nyomdászat története. Ajtai K. Albert Magyar Polgár Könyvnyomdája, Kvár. 1896. 94.

6 Simon Melinda: Josef Franz Kollmann eddig ismeretlen kiadói jelvényei. Magyar grafika (2010). 2 sz. 76. 
már múködött könyvkereskedés Marosvásárhelyen Huszár Antal által, illetve Brassóban is a Reich testvérek és Wagner János András révén.

Az 1800-as évek elején Kolozsváron elsősorban a nyomdák és könyvkötők foglalkoztak könyvek eladásával. Korábban a régi könyvek árusítását a protestáns kollégiumokban rendezett könyvaukciók segítségével bonyolították, azonban ez megváltozott a könyvkereskedések megalakulásával. Hochmeister kolozsvári kereskedésében sok bel- és külföldi könyvet tartott: ábécés könyvek, naptárak, regények, népszerű gazdasági és orvosi munkák voltak fellelhetők. ${ }^{7}$ Nyomtatott katalógusai révén hirdette készletét német és magyar nyelven. Más vállalkozásokkal is kiegészítette jövedelmét, hiszen nyomdász és könyvkötő is volt, később könyvkiadó és vállalkozó is volt egy személyben. A könyvkereskedése azonban 1809-ben megszűnt, és az ezt követő periódusban könyvkötők és Tilsch János bécsi származású kereskedő látta el a kolozsvári olvasóközönséget.

I. Ferenc szigorú cenzúrarendeletet léptetett életbe a magyar jakobinus mozgalom elfojtása után, újracenzúrázó bizottságokat hozott létre, amely újra megvizsgálta a korábban kiadott és az országba behozott műveket - megnehezítve és akadályozva ezzel a reformkori könyvkiadás és könyvkereskedelem fejlődését. ${ }^{8}$ Számos könyvet és időszaki kiadványt tiltottak be ennek következtében, viszont annyit sikerült elérniük a reformeszmék híveinek, hogy 1840ben kivették az irányítást a bécsi rendőrminisztérium kezéből és a Budán múködő könyvvizsgáló hivatalra bízták. A rendelet értelmében a könyvkötők továbbra is árusíthattak tankönyveket, imakönyveket és kalendáriumokat, illetve maguk is kiadhattak. Pontosan elhatárolta egymástól a könyvárust és az antikváriust. Míg a könyvárusnak joga volt bekötött és bekötetlen, régi és új könyvekkel kereskednie, valamint átvehetett kiadásra, továbbításra, eladásra vagy cserébe szánt munkákat, addig az antikvárius kizárólag régi és bekötött könyvekkel kereskedhetett. ${ }^{9}$ Világos, hogy az államhatalmi szervek célja a nyomdatermékek előállítása és terjesztése fölötti politikai ellenőrzés volt.

A könyvkereskedelem főként a nagyvárosokban bonyolódott le és legfontosabb tényezői a könyvkötők maradtak. 1808-ban Gróf Bánffy György erősítette meg és adta ki a könyvkötők új szabályait (Bárdi István, Ajtai Kovács István, Lőcsei Spielenberg Sámuel, Ajtai Kovács Sándor, Cseh Ferenc, Gilányi Mihály, Magyari István, Rischanyi Mátyás, Gutman János). Három részre oszlott az ötven cikkből álló szabályzat, az első a céheket, a második a legényeket, a harmadik pedig az írásokat tárgyalja. ${ }^{10}$ Újat hoz azzal, hogy határidőt szab az elvállalt munka elkészítésére, illetve a be nem tartásáért büntetést szab ki.

A század első felében három nyomda is működött Kolozsváron, melyeket a régi kollégiumi nyomdák utódaiként általában a könyvkereskedők múködtettek, úgy mint: Akosi Barra Gábor, Tilsch János, Stein János. A kiadó-könyvkereskedők - a nyomdász-kiadók mellett jelentékeny részt vállaltak a reformkori könyvtermelés előállításában. A kiadók, nyomdák vagy akár a szerzők maguk is foglalkoztak terjesztéssel. Azonban sem a kiadók bizományosai, sem pedig az antikvár kereskedők nem kizárólag könyvekkel, hanem legkülönbözőbb egyéb áruval is kereskedtek. A könyvbizományosi fogalom azt jelentette, hogy a vidéki könyvárus-

7 VITA Zsigmond: Tudománnyal és cselekedettel. Irodalmi Könyvkiadó, Buk., 1968. 225.

8 Fülöp Géza: A Magyar könyvkultúra története 1945-ig. = Könyvkiadók és könyvterjesztôk Magyarországon. Szerk. Zöld Ferenc. Magyar Könyvkiadók és Könyvterjesztők Egyesülése, Bp., 1987. 28.

9 VARga Sándor: A Magyar Könyvkereskedők Egyletének alapitása. Bp., 1980. 16.

10 Јакав Elek: Kolozsvár története. III. Bp., 1888, 591. 
nak - mint megbízónak - volt egy pesti könyvárus, és minden valamirevaló magyarországi könyvárusnak volt egy-egy lipcsei, bécsi, párizsi könyvárus bizományosa. A megbízó beszerzéseit saját székhelyén intézte a bizományos - ha kiadóként is múködött, raktáron tartotta és kezelte a kiadványokat, természetesen jutalék ellenében. ${ }^{11}$

Kolozsváron az első rendszeres könyvkereskedést 1830-as évek elején Tilsch János alapította, a másodikat Burián Pál és a harmadikat Barra Gábor 1836-ban. ${ }^{12}$ Még ebben az évben maga mellé veszi Stein Jánost, aki 1837-től egyedül vezeti a könyvkereskedést. 1842-től cégtársa lett özv. Barra Gáborné, így a cég neve: Özv. Barráné és Stein lett. ${ }^{13}$ Ami az első két könyvkereskedőt illeti, ellentmondásos adatok állnak rendelkezésünkre, hiszen maga Steinhofer is azt állítja egy korábbi kijelentésében, hogy 1832-ben nyitotta üzletét Burián, az információt Jakó Zsigmond is megerősíti tanulmányában - egy Burián által írt levelet idéz, melyben saját magát Erdély első antikváriusának nevezi, 1832. április 30-án. ${ }^{14}$

Ferenczi Zoltán szerint Tilsch előtt valódi könyvkereskedés nem volt Kolozsváron. ${ }^{15}$ Tilsch már a század elején rendelkezett nyomtatott könyvjegyzékkel, melyekben jelezte a nagyközönség számára a boltjában elérhető könyvek adatait. Elsősorban német nyelvű könyvek eladásával foglalkozott, de fellelhetők a magyar könyvek is nála. Mindezek mellett borbélymúhelyt is üzemeltetett, és feleségének meg divatszalonja volt ugyanitt. ${ }^{16}$ Bécsi utazásai során könyveket is hozott magával, és rájött, hogy növekszik irántuk az igény, így áttért könyvkereskedelemre. Az 1820-30-as években neki volt a legjelentősebb könyvesboltja Kolozsváron. Itt be lehetett szerezni a romantikus irodalmat: Vörösmarty, Fáy András, Széchenyi munkáit. Bogdánffi Gábor kolozsvári postamester írta 1830. február 27-én az olvasókabinetek hírlapbeszerzése kapcsán Carlovszky János fö-postaigazgatónak Szebenbe, hogy az egyik ilyen társaság Tilsch János könyvárus útján hozatja be a bel- és külföldi hírlapjait, a postahivatal közbenjárása nélkül, mert nem használja sem a lovas, sem a szekérpostát. De bármit is hozat, a könyvvizsgáló hivatalnak bemutatja. ${ }^{17}$ Szintén ezekben az években rendszeresen közölt könyvhirdetéseket az Erdélyi Híradó mellékletében, a Literaturai Hirdetményben: Schiller magyarra fordított verseit, Brassai, Bölöni Farkas és Jósika Miklós munkáit.

Az 1830-as években új, céltudatos értelmiség volt kialakulóban, megteremtve ezzel azt az olvasóközönséget, melyre az önálló könyvkereskedelemnek szüksége volt. Legtöbbször már könyvkiadásra is vállalkoztak, kezdett közeledni az író és könyvkereskedő. Megnőtt a kolozsvári könyvforgalom, így a Burián Pál által alapított antikvárium is fontos helyet foglalt el ezen a piacon. Nagy választéka volt klasszikusokban, és sok értékes könyvet szerzett be az írók és könyvgyưjtők számára. 1820. február 5-én már budai és nagyváradi könyvkereskedőnek neve-

11 VARGA: i.m. 23.

12 VITA Zsigmond: Erdélyi könyvkereskedôk és katalógusaik a felvilágosodás korában és a reformkorban. Könyv és Könyvtár (1966). 5. sz. 69.

13 Steinof ER Károly: A könyv története. I. Lampel R. Kk. R.T. könyvkiadóvállalata, Bp., 1915. Iparosok olvasótára XXI(1915). 1-3 sz., 115.

14 Jако́ Zsigmond: Az erdélyi magyar antikvár kereskedelem kezdeteiröl = Múvelödési törekvések a kora üjkorban. Tanulmányok Keserü Bálint tiszteletére. Szerk. Balázs Mihály-Font Zsuzsa-Keserü Gizella-Öтvös Péter. József Attila Tudományegyetem Régi Magyar Irodalom Tanszéke, Szeged, 1997. 223. (a továbbiakban Jakó: Az erdélyi magyar.)

15 FERENCZI: $i . m .99$.

16 ЈАКó: Az erdélyi magyar. 229.

17 ЈакАв: i.m. 772. 
zi magát, amikor az erdélyi Főkormányszéktől kéri az engedélyt Kolozsváron kölcsönkönyvtár és könyvkereskedés nyitására. ${ }^{18}$ Feltehetően jól átgondolt üzleti terv kapcsán települt át Erdélybe, a fővárosi konkurencia, a tőkeerős német kereskedők által uralt magyarországi könyvpiacon nehezebben érvényesült. Az erdélyi piac megszerzésével viszont szolgálhatta a magyar irodalom és tudomány kibontakozását, illetve növelhette a magyar nyelvü olvasóközönséget. ${ }^{19}$ Széles körű összeköttetései voltak magyar írókkal és könyvgyưjtőkkel, segítséget nyújtva akár hozzáférhetetlennek hitt kötetek beszerzésében és könyvtáraik gazdagításában. A latin klasszikusok terjesztése terén nagy érdemei voltak Kolozsváron. Kazinczy például nagyra tartotta Burián munkásságát, hiszen régi könyvek érdekében mindig hozzá fordult. Nem volt ezen a véleményen Bölöni Farkas Sándor, amint az levelezéséből kiderül, már 1828ban említi Burián katalógusát: „Mely sok szemét könyv. [...] Burjánnál hazugabb művész nem igen lehet. Tilsch is nagy csaló; de én úgy zabolázom zsidóságát, hogy a könyvárusi cathalogusokat viszem magammal, az ő perczentjét felvetem s így fizetem ki. Rajtam - úgymond tovább - nem veszen sokat, mivel tudja, hogy a bécsi cathalogusokra figyelmezek s mindennek tudom perczentjét". ${ }^{20}$

Maga Jakab Elek így vélekedik róla: „leleményes ügyességénél fogva meg tudott szerezni jópénzért bármit, amire a magyar tudósnak és gyưjtőnek szüksége s elegendő pénze volt; s ez irányunkban érdem; de viszont megszerzett elszegényültektől, s a tudományt nem becsülőktől a német, francia és angol vagy más antikvárius számára is mindent, s ez utóbbival irodalomtörténetünknek s múzeumainknak néha valóban kárt tett. De azért az irodalom és kivált régiségek minden barátja mégis áldja emlékét. Bár adta volna Isten kutató és gyűjtő szellemét s régi irodalmunk iránti nemes szenvedélyét valamelyik újabb könyvárusunknak örökségül!" ${ }^{21}$

Tilschhez hasonlóan számozott könyvhirdetéseket adott ki, az 1840-es években a vagyonosabb vevők számára pedig egy katalógust 40 oldal terjedelemben, 1-5. szám: „Burián Pál könyvárusnál Kolozsvárt megszerezhetni pengő pénzben, úgy mint:"22 címmel. Részletesen ismerteti a címeit a magyar, német, latin és kevesebb francia nyelvü műnek. Elsősorban 18-19. századi latin és német munkák lelhetők fel a katalógusban, de 16. századi humanista kiadványokat is találunk benne. A legritkább külföldi kiadásokat is beszerezte vásárlói számára. Kapcsolatban volt olyan kiadókkal, mint a bécsi Singrenius, a bázeli Frobenius, Elzevir vagy a leideni Gryphius. A ritkaságok közül megemlíthetjük Erasmus Colloquiorum formulae et alia címú munkája 1521-es kiadását, illetve Martialis 1517-es velencei kiadását.

Burián Pál szakképzettsége és múveltsége révén kimagaslott korának könyvkereskedői, nyomdász és könyvkötő iparosai közül. Kolozsvári működése határkövet jelent az erdélyi magyar könyvkereskedelemben.

Barra Gábor, aki a református kollégium nyomdájának igazgatója is volt, 1836-ban nyitotta meg könyvkereskedését. ${ }^{23}$ Tervezte egy könyvtájékoztató lap kiadását, a raktáron lévő dokumentumainak az ismertetésére, hogy segítse az írók, kutatók munkáját. Sajnos azonban

18 Jакó Zsigmond: Burián Pál (1790-1860), Erdély elsö antikváriusa = R. Várkonyi Ágnes emlékkönyv. Szerk. Tusor Péter. ELTE Bölcsészettudományi Kara, Bp., 1998. 525.

19 Uo. 527.

20 Idézi: Jакав Elek: Bölöni Farkas Sándor és kora. Keresztény Magvető V(1870). 4. sz. 271.

21 Uo. 271.

22 Nyomtatott katalógus, Kolozsvári Lucian Blaga Központi Egyetemi Könyvtár.

23 VITA Zsigmond: Tudománnyal és cselekedettel. Irodalmi Könyvkiadó, Buk., 1968. 227. 
korai halála meggátolta tervei véghezvitelében, 1837. december 17-én, 38 éves korában meghalt. ${ }^{24}$ Számozott könyvhirdetései erdélyi történeti munkák, tankönyvek, drámák, imádságos könyvek kínálatáról tanúskodnak. Raktáron tartotta mindazt, amire az iskoláknak és olvasóknak szüksége volt, hiszen egy jól felszerelt könyv- és papírkereskedést tartott fenn. Könyvkereskedését özvegye és üzlettársa, Stein János folytatta (Özv. Barráné és Stein).

Barra segédnek hívta meg a tehetséges ifjút, folyamatosan dicsérte, ami megkettőzte szorgalmát, és arra motiválta, hogy tovább müvelje magát és megfeleljen a kérelmeknek. Nekilátott a német nyelv tanulásának, később kiváló német levelezô is vált belőle, valamint franciául is tanult. Kereskedésében nemcsak a magyar irodalomra fektette a hangsúlyt, hanem különös figyelmet fordított a külföldi irodalom megszerzésére is. Felvette a kapcsolatot Németország, Párizs és London könyvkereskedőivel, és megszerezte közönsége számára a leghasznosabb tudományos és szépirodalmi múveket. Kiterjesztve piacát, Nagyenyeden és Marosvásárhelyen is kereskedést nyitott. Önálló kiadói tevékenységet is folytatott, és a 40-es években már olyan ismert szakember lett, hogy Emich, Heckenast és Geibel kiadványaikra nézve csereviszonyba léptek vele. ${ }^{25} \mathrm{Az}$ 50-es évek elején jóformán újra kellett kezdenie életét, mert a Kossuth-bankók miatt nagy veszteségek érték, azonban átvészelte a nehézségeket, és növelte üzletét. Titokban röpiratokat terjesztett ebben az időszakban, és megvásárolta a várfogságra ítélt Tilsch raktárát, ami által az egész erdélyi magyar irodalom a kezébe került. 1855-ben pedig saját nevén folytatta, ugyanis megvásárolta özv. Barráné üzleti részét. Kiváló üzletember volt, aki társadalmi jelentőséget próbált üzletének biztosítani. Gyulai Pál - a református kollégium tanára - „szellemi csárdának” nevezte Stein könyvkereskedését. ${ }^{26}$ Állandó vendégvásárló volt: Kriza János, Nagy Péter, Takács János, Kovács Antal pedagógusok, illetve a polihisztor Brassai Sámuel is. Itt tájékozódhattak az éppen frissen megjelent kötetekről, kifejtették véleményüket róluk és az aktuális kérdésekről. Naponta sor került egy-egy ilyen összejövetelre, ahol a szellemi előkelőségek megvitatták nézeteiket.

Kiadásaiban megtaláljuk elsősorban az egyházi műveket (kézi-, tan-, ima- és énekeskönyvek), de van tudományos tárgyú (földrajz, történelem, természet- és orvostudomány) kiadványa is. Az 1870-es években - az egyetem alapítása után - megszerezte a magyar királyi egyetem kizárólagos szállítója címet. ${ }^{27}$ Ebben az időszakban lassan át is adja kereskedése vezetését fiának, Gábornak. ${ }^{28}$ Ő maga inkább a reformátusoktól bérelt nyomdában tevékenykedett, és építette tovább az erdélyi kultúrát mint könyv- és lapkiadó. 1886. aug. 14-én bekövetkezett halálakor az erdélyi közművelődés egyik erős támaszát veszítette el, hiszen munkásságán végigkövethető a kultúra és irodalom művelése. Kiadványai közül kiemelendő: Wolfart Új testamentuma, a Finály-Régeni-féle Latin-magyar szótár, Mikó Imre: Erdélyi történeti adatok, Kriza János: Vadrózsák című kötete.

Említést érdemel még Demjén László bel- és külirodalmi könyv-, mű- és hangjegykereskedése. Kiadóként is müködött, de sajnos nagyon keveset tudunk életéről és munkásságáról,

24 FERENCZI: $i . m .98$.

25 Uo. 101.

26 VÁRADY Aurél: A régi bolt s a régi könyvbarátok. Pásztortűz XIII(1927). 16. sz. 365.

27 Uo. 366.

28 A fótéri könyvkereskedést - berendezésével és készleteivel együtt - 1920. december 15-én megvásárolta a Minerva, és később itt folytatta könyvforgalmazási tevékenységét. (Az üzlet a Belközép utca, ma Eroilor utca 4. szám alatt múködött.) 
nagyrészt, amennyit a kiadott kötetei elárulnak róla. 1861-ben az ő bizományában jelent meg Kőváry László Okmánytára. Az 1862 és '63-as évre „Kolozsvári naptár”-at adott ki, melyben hirdeti azon köteteket, melyek könyvkereskedésében megvásárolhatók: Erdélyi fejedelmek képcsarnoka, Az erdélyi fejedelmek életrajza, valamint Helység-névtár - Gámán Zsigmond összeállításában. ${ }^{29}$ Hirdetései szerint készletében vannak a magyar irodalom legújabb termékei, melyeket házhoz is küldhet megtekintés végett. Továbbá kész a meg nem lévők gyors és pontos megszerzésére, valamint ajánlja a német és francia irodalom választékos felhozatalát is. A legfontosabb pesti kiadóktól nyert Erdély számára raktárt, úgy mint: Magyar Akadémia, Heckenast Gusztáv, Eggenberger F., Emich Gusztáv, Kilián, Lampel, Ráth Mór stb. Az 1878-as statisztikai kimutatás ${ }^{30}$ még említi mint könyvterjesztői céget Kolozsváron.

A reformkor vezető politikusai igyekeztek olyan lépéseket kieszközölni, melyek a műveltség színvonalának emelésére szolgáltak, hiszen a polgári haladás magas kulturális színvonalat igényelt. Megnövekedett az érdeklődés a politika iránt, ennek következtében fellendült a politikai publicisztika és hírlapirodalom. 1851-ben viszont főispáni rendelet kimondja, hogy a külföldi sajtótermékek közül a könyvkereskedők csak azokat árulhatják, melyekre terjesztési engedélyt kaptak. ${ }^{31} \mathrm{~A}$ hatósági felügyelet megerősödött, így a kereskedők nem mertek tiltott könyveket arusítani. Vidéken a könyvkereskedések mellett folytatódott az alkalmi és házaló könyvárusok múködése is. Révai Sámuel fontosnak tartotta a vidéki könyvkereskedôk állandó noszogatását, unszolását: „... mert a vállalat biztos jövője csakis a szortimenter kezében van. De azt állandóan bíztatni kell, mert nem olyan óra az, amit egy évben csak egyszer kell felhúzni, mert: minden nap meg kell győzödni a gépezet helyes voltáról, minden nap meg kell azt olajozni és felhúzni! Akkor pompásan fog járni”. ${ }^{32}$ A könyvkereskedelem 19. századi közművelődés szerves részét képezte, és számottevő tényezője volt, hiszen e század folyamán kiemelkedett maradi állapotából, és modern üzletággá fejlődött - közvetítette a nemzeti kultúrát kiadóként és terjesztőként is. Számos kritikára adott alkalmat a működésük, a lassú közlekedést és drága szállítást nehezményezték elsősorban, továbbá az írók sokallták a bizományi díjként elvett összegeket (20-25\%). Mindezek ellenére tevékenységükön keresztül a hosszú 19. század világának több szegmense nyomon követhető: kereskedelem, politika, tudomány, kultúra, közélet.

A 19. század fordulóján már ezt írja Kosztolányi:

„A régi magyar könyvkereskedők szívvel lélekkel és sok-sok szeretettel kezelték a könyvet, mely minden nemzetnek a legszentebb hazai portékája. [...] Az angol származású Gibbon, a francia származású Lepage és a német származású Stein. Ezeké volt Kolozsvár három magyar könyvkereskedése.

29 Kolozsvári naptár. I(1862), II(1863), Kiadja Demjén László, Kvár.

30 VARGA: $i . m .149$.

31 Fülöp Géza: A könyv-és könyvtári kultúra a kapitalizmus idöszakában (1789-1917). I. Nemzeti Tankönyvkiadó, Bp., 1993. 231.

32 RÉvay Mór János: Irók, könyvek, kiadók. Egy magyar könyvkiadó emlékiratai. I. Révai Testvérek Irodalmi Intézeti Részvénytársaság kiadása, Bp., 1920.59. 
Tanulhatott volna tőlük Az Est, az Athenaeum és a Beszerzési könyvosztálya, hogy miként kell magyar nemzeti kultúrát terjeszteni”. ${ }^{33}$

\section{BOOKSELLERS AND BOOKBINDERS IN THE 19 ${ }^{\mathrm{TH}}$ CENTURY CLUJ}

\section{Keywords: booksellers, bookshops, printing, book purchase, Cluj}

At the beginning of the $19^{\text {th }}$ century book trading was first dealt by printing houses and bookbinders. Later, besides printing-publishing houses, editor-booksellers had a significant role in the production of books in Cluj. By 1830 there were three renowned booksellers in the town: János Tilsch, Pál Burián, Gábor Barra. Publications available in their shops were made known using lists of printed books, their stock consisting mostly of books in German, but writings in Hungarian were also offered. János Stein - former assistant of Barra - opened his bookshop in 1838, which operated throughout the century, his son Gábor continuing his work from the '70s.

The history of these libraries is a significant factor and an integral part of the Transylvanian Hungarian culture and civilization. Through promoting the national culture as publishers and distributors, their work is representative for many commercial and political aspects, as well as for the scientific and public life of the $19^{\text {th }}$ century.

\section{LIBRARI ŞI LEGĂTORI DE CĂRŢI ÎN CLUJUL SECOLULUI AL XIX-LEA}

\section{Cuvinte-cheie: librari, librării, tipar, achiziţie carte, Cluj}

La începutul secolului al XIX-lea cei de comercializarea cărţilor s-au ocupat în primul rând tipografiile și legătorii de cărţi. Mai târziu editorii-librari - pe lângă tipografii-edituri - au avut un rol semnificativ în producţia de cărţi din Cluj. Prin anii 1830 existau în oraș trei librari renumiţi: Tilsch János, Burián Pál, Barra Gábor. Au făcut cunoscute publicaţiile disponibile în magazinele lor cu ajutorul listelor de cărţi tipărite, având pe stoc cărţi în limba germană - în cea mai mare parte, dar au fost oferite și scrieri în limba maghiară. Stein János - fostul asistent al lui Barra - și-a deschis librăria în 1838, care a funcţionat pe tot parcursul secolului, continuând activitatea lui, din anii '70, fiul său, Gábor.

Istoria acestor librării constituie un factor semnificativ și parte integrantă a culturii și civilizaţiei maghiare din Transilvania, promovând cultura naţională ca editor și distribuitor. Activitatea lor este reprezentativă pentru mai multe aspecte comerciale, politice, precum și pentru viaţa știinţifică și viaţa publică a secolului al XIX-lea.

33 Lengyel András: Egy anonim Kosztolányi-cikk azonositása. Móra Ferenc Múzeum Évkönyve (2008). 11. sz. 261-262. 